\title{
Nutritional evaluation of elephant-grass silages with different levels of by-products from the cashew juice industry
}

\section{Ana Cristina Holanda Ferreira ${ }^{1}$, Norberto Mario Rodriguez ${ }^{2}$, José Neuman Miranda Neiva ${ }^{1}$, Patrícia Guimarães Pimentel ${ }^{3}$, Silas Primola Gomes ${ }^{4}$, Warley Efrem Campos ${ }^{5}$, Fernando César Ferraz Lopes ${ }^{6}$}

\author{
${ }^{1}$ Universidade Federal do Tocantins, Escola de Medicina Veterinária e Zootecnia, Araguaína, TO, Brasil. \\ 2 Universidade Federal de Minas Gerais, Escola de Veterinária, Departamento de Zootecnia, Belo Horizonte, MG, Brasil. \\ ${ }^{3}$ Universidade Federal do Ceará, Departamento de Zootecnia, Fortaleza, CE, Brasil. \\ ${ }^{4}$ Universidade da Integração Internacional da Lusofonia Afro-Brasileira, Instituto de Desenvolvimento Rural, Redenção, CE, Brasil. \\ ${ }^{5}$ Ministério da Agricultura, Pecuária e Abastecimento, Departamento de Fiscalização de Insumos Pecuários, Brasília, DF, Brasil. \\ ${ }^{6}$ Empresa Brasileira de Pesquisa Agropecuária, Centro Nacional de Pesquisa de Gado de Leite, Juiz de Fora, MG, Brasil.
}

\begin{abstract}
This study was conducted to evaluate the intake, apparent digestibility (AD), and degradability in situ of elephant grass (Pennisetum purpureum Schum) silages containing 0, 35.0, 70.0, 105.0, and $140.0 \mathrm{~g} \mathrm{~kg}^{-1}$ by-product from dried cashew apple (DCBP) (as fed basis). A completely randomized design with four replicates was adopted. For the study of degradability in situ, one adult male cattle was used in a completely randomized design with split plots. Intake and AD of dry matter (DM), crude protein (CP), neutral detergent fiber (NDF), acid detergent fiber (ADF), hemicellulose, and cellulose were evaluated, and the digestible energy (DE) and nitrogen balance (NB) of the silages were determined. The degradability in situ of DM, CP, and NDF was also determined. Addition of DCBP provided an increase in the intakes of DM, CP, NDF, and ADF. No effects of the levels of addition of DCBP were observed on the coefficients of AD of the silages. Regarding NB, positive values were only detected in the treatment with $105.0 \mathrm{~g} \mathrm{~kg}^{-1}$ DCBP. In the analysis of the degradability in situ, the incubation periods increased the rates of disappearance of DM, CP, and NDF. However, no effect of the levels of DCBP were observed on the effective degradability of DM. The by-product from dried cashew apple can be included at up to $140.0 \mathrm{~g} \mathrm{~kg}^{-1}$ in silages of elephant grass, but the high contents of acid detergent insoluble nitrogen may compromise the use and availability of nitrogen to the animals.
\end{abstract}

Key Words: agro-industrial waste, digestibility, intake, in situ degradation, nitrogen balance

\section{Introduction}

Among the numerous existing agricultural by-products, the waste from the cashew (Anacardium occidentale L.) processing industry has an important place in the agroindustry of the northeast region of Brazil. According to Luciano et al. (2011), only $15 \%$ of the production of cashew apple is utilized commercially in human feeding. It is noteworthy that the production of this fruit is concentrated in the dry season of the year, the period of low roughage production and during which the prices of grains and commercial concentrates increase.

In this regard, the by-products resulting from the extraction of the juice from the cashew apple and from the cashew apples unsuitable for human consumption are

Received March 31, 2015 and accepted August 21, 2015.

Corresponding author: pgpimentel@hotmail.com

http://dx.doi.org/10.1590/S1806-92902015001200004

Copyright (C) 2015 Sociedade Brasileira de Zootecnia. This is an Open Access article distributed under the terms of the Creative Commons Attribution License (http://creativecommons.org/licenses/by/4.0/), which permits unrestricted use, distribution, and reproduction in any medium, provided the original work is properly cited. already being used in animal feeding (Dantas Filho et al., 2007; Borges et al., 2001; Silva et al., 2011). Yet some studies describe that the presence of high lignin (Ferreira et al., 2004), tannin (Agostini-Costa et al., 2003), and acid detergent insoluble nitrogen (ADIN) contents (Ferreira et al., 2007; Rêgo et al., 2010b; Teles et al., 2010) in the cashew apple may influence the intake and apparent digestibility (AD) of these materials.

Other limitations for the use of by-products are the high moisture and fiber contents, which may adversely affect its direct use in animal feeding. Thus, forms of use that improve the exploitation of the by-product, such as drying and ensilage, require further studies.

The ensiling technique is one of the main ways of forage preservation. Among the different forages, elephant grass (Pennisetum purpureum Schum) is used mainly for its high yield. However, the high moisture content and low concentration of soluble carbohydrates in the plant are limitations to the ensiling process. Evaluating chemical and fermentative traits of elephant grass ensiled with increasing levels of by-product from the cashew agro-industry, Ferreira et al. (2004) observed that the addition of cashew bagasse 
improved the nutritive value and preservation of silage, displaying potential to be used in sheep nutrition.

Thus, this experiment was conducted to evaluate the effect of levels of the by-product from dried cashew apple (DCBP) added to the ensilage of elephant-grass on the intake and $\mathrm{AD}$ of nutrients and on the digestible energy (DE) and nitrogen balance (NB) of sheep. The effects of the levels of addition on the degradability in situ of the nutrients were also evaluated.

\section{Material and Methods}

Five levels of inclusion of DCBP $(0,35.0,70.0$, 105.0 , and $140.0 \mathrm{~g} \mathrm{~kg}^{-1}$, as fed) were used in the ensilage of the elephant grass, which was harvested manually, at approximately 70 days of growth, and processed through a conventional forage shredder machine to a particle size of 1 to $2 \mathrm{~cm}$ (Tables 1 and 2). Later, the chopped grass was mixed with the DCBP, which was acquired from the processing of the fruit for the extraction of juices and pulps at the company MAISA, located in Mossoró-RN, Brazil.

Table 1 - Chemical composition of the feedstuffs

\begin{tabular}{lcc}
\hline Item & Elephant grass & DCBP \\
\hline Dry matter & 195.7 & 860.0 \\
Crude protein $\left(\mathrm{g} \mathrm{kg}^{-1} \mathrm{DM}\right)$ & 49.8 & 182.6 \\
$\mathrm{NDF}\left(\mathrm{g} \mathrm{kg}^{-1} \mathrm{DM}\right)$ & 707.5 & 722.3 \\
$\mathrm{ADF}\left(\mathrm{g} \mathrm{kg}^{-1} \mathrm{DM}\right)$ & 392.1 & 565.6 \\
Hemicellulose $\left(\mathrm{g} \mathrm{kg}^{-1} \mathrm{DM}\right)$ & 315.3 & 156.7 \\
Cellulose $\left(\mathrm{g} \mathrm{kg}^{-1} \mathrm{DM}\right)$ & 253.2 & 210.2 \\
Lignin $\left(\mathrm{g} \mathrm{kg}^{-1} \mathrm{DM}\right)$ & 138.9 & 355.4 \\
NDIN & 293.4 & 512.3 \\
ADIN & 105.9 & 167.0 \\
\hline
\end{tabular}

DCBP - by-product from dried cashew apple.

DM - dry matter; CP - crude protein; NDF - neutral detergent fiber; ADF - acid detergent fiber; NDIN - neutral detergent insoluble nitrogen $\left(\mathrm{g} \mathrm{kg}^{-1}\right.$ of total nitrogen); ADIN - acid detergent insoluble nitrogen ( $\mathrm{g} \mathrm{kg}^{-1}$ of total nitrogen).

Table 2 - Chemical composition of the silages

\begin{tabular}{|c|c|c|c|c|c|}
\hline \multirow[b]{2}{*}{ Item } & \multicolumn{5}{|c|}{ DCBP } \\
\hline & 0.0 & 35.0 & 70.0 & 105.0 & 140.0 \\
\hline Dry matter & 198.4 & 210.4 & 221.2 & 253.5 & 270.5 \\
\hline Crude protein $\left(\mathrm{g} \mathrm{kg}^{-1} \mathrm{DM}\right)$ & 46.7 & 54.4 & 70.8 & 81.2 & 91.0 \\
\hline $\mathrm{NDF}\left(\mathrm{g} \mathrm{kg}^{-1} \mathrm{DM}\right)$ & 731.3 & 738.7 & 740.0 & 714.3 & 719.4 \\
\hline $\mathrm{ADF}\left(\mathrm{g} \mathrm{kg}^{-1} \mathrm{DM}\right)$ & 453.5 & 487.8 & 482.4 & 470.6 & 493.2 \\
\hline Hemicellulose $\left(\mathrm{g} \mathrm{kg}^{-1} \mathrm{DM}\right)$ & 277.8 & 250.9 & 257.6 & 243.7 & 226.2 \\
\hline Cellulose $\left(\mathrm{g} \mathrm{kg}^{-1} \mathrm{DM}\right)$ & 314.3 & 314.9 & 290.6 & 255.8 & 234.6 \\
\hline Lignin $\left(\mathrm{g} \mathrm{kg}^{-1} \mathrm{DM}\right)$ & 133.4 & 165.1 & 181.8 & 202.9 & 243.6 \\
\hline NDIN & 269.8 & 419.5 & 459.4 & 466.3 & 574.6 \\
\hline ADIN & 117.1 & 214.0 & 192.1 & 210.8 & 247.5 \\
\hline
\end{tabular}

DCBP - by-product from dried cashew apple.

NDF - neutral detergent fiber; ADF - acid detergent fiber; NDIN - neutral detergent insoluble nitrogen ( $\mathrm{g} \mathrm{kg}^{-1}$ of total nitrogen); ADIN - acid detergent insoluble nitrogen $\left(\mathrm{g} \mathrm{kg}^{-1}\right.$ of total nitrogen).
The by-product was composed basically of the cashew bagasse resulting from the processing of the apple for juice making. The material was dried in the sun on a cemented floor for $48 \mathrm{~h}$, scattered in layers of approximately $7 \mathrm{~cm}$ in thickness, and turned over at least three times daily until it reached 130.0 to $160.0 \mathrm{~g} \mathrm{~kg}^{-1}$ moisture. At night, the material was piled and covered with canvass to avoid accumulation of moisture.

The experimental silos consisted of plastic drums with 210 L capacity. After weighing and homogenizing the elephant grass with the DCBP, the material was inserted into the silos (126 kg silage, at a density of $600 \mathrm{~kg} \mathrm{~m}^{-3}$ ) and compressed. After the silos were filled up, they were closed with plastic canvas secured with rubber bands.

To evaluate the intake and $\mathrm{AD}$ of the silages and determine NB, 20 uncastrated sheep of an undefined breed, with an average live weight (LW) of $24.0 \pm 2.0 \mathrm{~kg}$, were distributed in a completely randomized design with five levels and four replicates, considering each animal an experimental unit. For each animal, the silage from a single experimental silo was used. Animals were weighed at the onset and end of the experiment, dewormed, and distributed randomly into each level of DCBP evaluated. Animals were kept in individual metabolic cages provided with collectors and separators of feces and urine, troughs, and drinkers to supply the feed, mineral mixture, and water ad libitum.

The experiment lasted 21 days, 14 of which were used for the animals to acclimate to the diets and experimental period, and seven to evaluate voluntary intake, the $\mathrm{AD}$ of nutrients, and NB.

The silages were supplied daily in two periods: morning $(06.30 \mathrm{~h})$ and afternoon $(15.30 \mathrm{~h})$, and the amount was calculated according to the intake of the previous days, allowing for approximately $150.0 \mathrm{~g} \mathrm{~kg}^{-1}$ as orts. Samples of the silages $(100 \mathrm{~g})$ were removed daily at the moment of weighing the feed for each animal, during the entire data-collection period, conditioned in plastic bags, labeled, and stored in a freezer at $-10^{\circ} \mathrm{C}$. At the end of the experiment, samples referring to each animal were thawed and homogenized, and a $300 \mathrm{~g}$ aliquot was collected and processed (pre-dried) for subsequent analyses. The orts were weighed in the morning, before the supply of the new feed, and sampled ( $80 \mathrm{~g}$ ) through the same procedure described for the sampling of the supplied feed.

Feces were collected during the evaluation period, and a $10 \%$ sample was taken and conditioned in a freezer at $-10{ }^{\circ} \mathrm{C}$. At the end of the experiment, samples referring to each animal were thawed and homogenized to remove $300 \mathrm{~g}$ of the total feces from each animal, which were conditioned in plastic bags, labeled, and kept in a freezer at $-10^{\circ} \mathrm{C}$. 
Twenty milliliters of hydrochloric acid $(\mathrm{HCl})$ were added to the urine-collection containers at a 1:1 ratio to prevent losses of nitrogen by volatilization. The urine was measured in the morning and afternoon during the evaluation period, when $10 \%$ aliquots were taken from the total and conditioned in a freezer at $-10{ }^{\circ} \mathrm{C}$ until the analyses.

The dry matter (DM), organic matter (OM), crude protein (CP), neutral detergent fiber (NDF), acid detergent fiber (ADF), hemicellulose, cellulose, lignin, neutral detergent insoluble nitrogen (NDIN), and ADIN contents were determined in the silage samples. The levels of DM, CP, $\mathrm{NDF}, \mathrm{ADF}$, hemicellulose, and cellulose were determined in the samples of orts and feces. Analyses of DM and CP were conducted according to methodologies described by AOAC (1990; Methods 934.01 and 984.13, respectively). The levels of NDF, ADF, hemicellulose, cellulose, and lignin were analyzed in accordance with Van Soest et al. (1991). The concentrations of NDF were analyzed using $1 \mathrm{~g}$ of sample treated with heat-stable alpha-amylase and solubilized with $100 \mathrm{~mL}$ of neutral detergent solution and expressed without correction for residual nitrogen and ash. The levels of ADF were determined through sequential method and expressed without correction for residual nitrogen and ash. The levels of lignin were determined using solubilisation of cellulose with sulphuric acid $\left(\mathrm{H}_{2} \mathrm{SO}_{4} 72 \%\right)$ according to Van Soest et al. (1991). The NDIN and ADIN contents were determined according to methodologies described by Licitra et al. (1996).

With the values obtained in the chemical composition analysis, the intakes of nutrients and the coefficients of $\mathrm{AD}$ of the nutrients were determined. The quantities of feed supplied and orts left by each animal were recorded to estimate the intake. The coefficients of AD, DE, and NB of the diets were determined according to methodologies described by Silva and Leão (1979). The AD was calculated by subtracting the ingested DM by the excreted DM, divided by the ingested DM. The gross energy content (GE) of feeds, feces and urine was determined using a bomb calorimeter and the DE was calculated by difference. The values of nitrogen consumption (NC), nitrogen excreted in feces (NF), and nitrogen excreted in urine (NU) were obtained by multiplying nitrogen levels by the amounts of feed intake and of feces and urine excreted, and NB was calculated as $\mathrm{NB}=\mathrm{NC}-\mathrm{NF}-\mathrm{NU}$.

The study of degradability in situ was conducted using a rumen-fistulated steer (Tomich and Sampaio, 2004). The animal was fed corn silage supplemented with $1 \mathrm{~kg}$ concentrate daily, at $07.00 \mathrm{~h}$ and $16.00 \mathrm{~h}$. After 45 days of ensilage, silos were opened and samples of the silages were collected for the trial. Samples were pre-dried in a forced- ventilation oven at $60{ }^{\circ} \mathrm{C}$ for $72 \mathrm{~h}$, processed in a knife mill with $5 \mathrm{~mm}$ sieve, and homogenized for later incubation.

Five levels of addition of the by-product were tested, with three replicates and five times of incubation with an animal. The experimental design was completely randomized, with split-plots, in which the proportions of DCBP were the treatments (plots), the different silos were the replicates, and the incubation times were the sub-plots.

The feeds were incubated in $9 \times 20 \mathrm{~cm}$ nylon bags with $50 \mu \mathrm{m}$ porosity containing $10 \mathrm{~g}$ of the pre-dried material. Bags were inserted in the rumen at $08 \mathrm{~h} 00$ and removed in sequential order at $6,24,48$, and $96 \mathrm{~h}$, and then washed manually in running water. To determine zero time $(t=0)$, three nylon bags were used per treatment with the same amount of sample utilized for the other incubation times; these were sealed and washed manually in the same manner as the other times. Afterwards, they were dried in a forcedair oven at $60^{\circ} \mathrm{C}$ and weighed, and samples were analyzed to determine $\mathrm{DM}$ and $\mathrm{CP}$ according to methodologies described by AOAC (1990; Methods 934.01 and 984.13, respectively). The NDF level was determined in accordance with methodologies described by Van Soest et al. (1991).

Means were compared and coefficients of the model proposed by Ørskov and McDonald (1979) were determined using the SAS software (Statistical Analysis System, version 9.2). After determining the model parameters, the effective degradability (ED) was estimated by adopting the rumen passage rates of $0.02,0.05$, and $0.08 \mathrm{~h}^{-1}$ (McDonald, 1981).

The model was evaluated by Akaike's information criterion (AIC):

$$
\mathrm{AIC}=-2 \ln \mathrm{L}+2(\mathrm{p}+1),
$$

in which $\mathrm{L}$ is the likelihood function; $\mathrm{n}$ is the sample size; and $\mathrm{p}$ is the number of free parameters of the model.

Intake, apparent digestibility, and nitrogen balance data were analyzed using the MIXED procedure of SAS (Statistical Analysis System, version 9.2). The following statistical model was used: $Y_{i j}=\mu+\alpha_{i}+e_{i j}$, in which $Y_{i j}$ is the value observed for the dependent variable studied; $\mu$ is the overall mean; $\alpha_{i}$ is the effect of inclusion of DCBP; and $\mathrm{e}_{\mathrm{ij}}$ is the random error associated with each observation. The most suitable model for each variable was chosen based on the significance of the linear and quadratic coefficients, using Student's $t$ test at the probability levels of 0.01 and 0.05 , and in the coefficient of determination.

\section{Results}

The intake of dry matter (DM) from the silages increased as DCBP was added (Table 3). In the regression analysis, a 
linear effect $(\mathrm{P}<0.01)$ of the levels of DCBP was observed on the silage DM intake, which increased by $20.47 \mathrm{~g} \mathrm{~d}^{-1}$ with every $10.0 \mathrm{~g} \mathrm{~kg}^{-1}$ DCBP added to the silage (as fed basis).

Despite the low CP $\left(68.0 \mathrm{~g} \mathrm{~kg}^{-1} \mathrm{DM}\right)$ and high ADIN (196.0 $\left.\mathrm{g} \mathrm{kg}^{-1} \mathrm{DM}\right)$ contents of the silages, which may restrict intake by reducing the availability of nitrogen to the rumen microflora, and the high NDF levels $\left(728.0 \mathrm{~g} \mathrm{~kg}^{-1} \mathrm{DM}\right)$ of the silages, which reduce intake by the accumulation of fibrous mass in the rumen (Van Soest, 1994), the highest level of DCBP $\left(140.0 \mathrm{~g} \mathrm{~kg}^{-1}\right)$ provided an increase of approximately $80 \%(\mathrm{P}<0.01)$ in DMI as compared with the silage of elephant grass alone (Table 3 ). Thus, DCBP seems to have improved the nutritional properties of the elephant grass silage.

The levels of DCBP had a linear effect $(\mathrm{P}<0.01)$ on $\mathrm{CP}$ intake, which increased by $0.04 \mathrm{~g} \mathrm{~d}^{-1}$ or $0.04 \mathrm{~g} \mathrm{~kg}^{-1} \mathrm{~d}^{-1} \mathrm{LW}^{0.75}$ with every $10.0 \mathrm{~g} \mathrm{~kg}^{-1}$ DCBP added to the silage (as fed basis). Addition of DCBP provided an increase of over $200 \%$ in CP intake when 105.0 and $140 \mathrm{~g} \mathrm{~kg}^{-1}$ of DCBP (as fed basis) were used, compared with the silages of elephant grass (Table 3).

The intakes of neutral detergent fiber (NDF) and acid detergent fiber (ADF), in $\mathrm{g} \mathrm{d}^{-1}$ and $\mathrm{g} \mathrm{kg}^{-1} \mathrm{~d}^{-1} \mathrm{LW}^{0.75}$, increased linearly $(\mathrm{P}<0.01)$ with the levels of DCBP used in the ensilage of elephant grass (Table 3 ).

Regarding the intakes of hemicellulose and cellulose, no effect of the levels of addition of DCBP in the ensilage of elephant grass was recorded $(\mathrm{P}>0.05)$. The mean values observed for hemicellulose intake were $119.49 \mathrm{~g} \mathrm{~d}^{-1}$ and $5.5 \mathrm{~g} \mathrm{~kg}^{-1} \mathrm{~d}^{-1} \mathrm{LW}$. Mean values for cellulose intake were $122.01 \mathrm{~g} \mathrm{~d}^{-1}$ and $5.7 \mathrm{~g} \mathrm{~kg}^{-1} \mathrm{~d}^{-1} \mathrm{LW}$ (Table 3).

The digestible DM, CP, and NDF intake values and the DE intake increased linearly $(\mathrm{P}<0.01)$ with the addition of DCBP, by $8.25 \mathrm{~g} \mathrm{~d}^{-1}, 0.04 \mathrm{~g} \mathrm{~d}^{-1}, 5.88 \mathrm{~g} \mathrm{~d}^{-1}$, and $0.03 \mathrm{Mcal} \mathrm{d}^{-1}$,

Table 3 - Regression equations and coefficients of determination $\left(\mathrm{R}^{2}\right)$ for the intakes of nutrients and digestible energy from silages

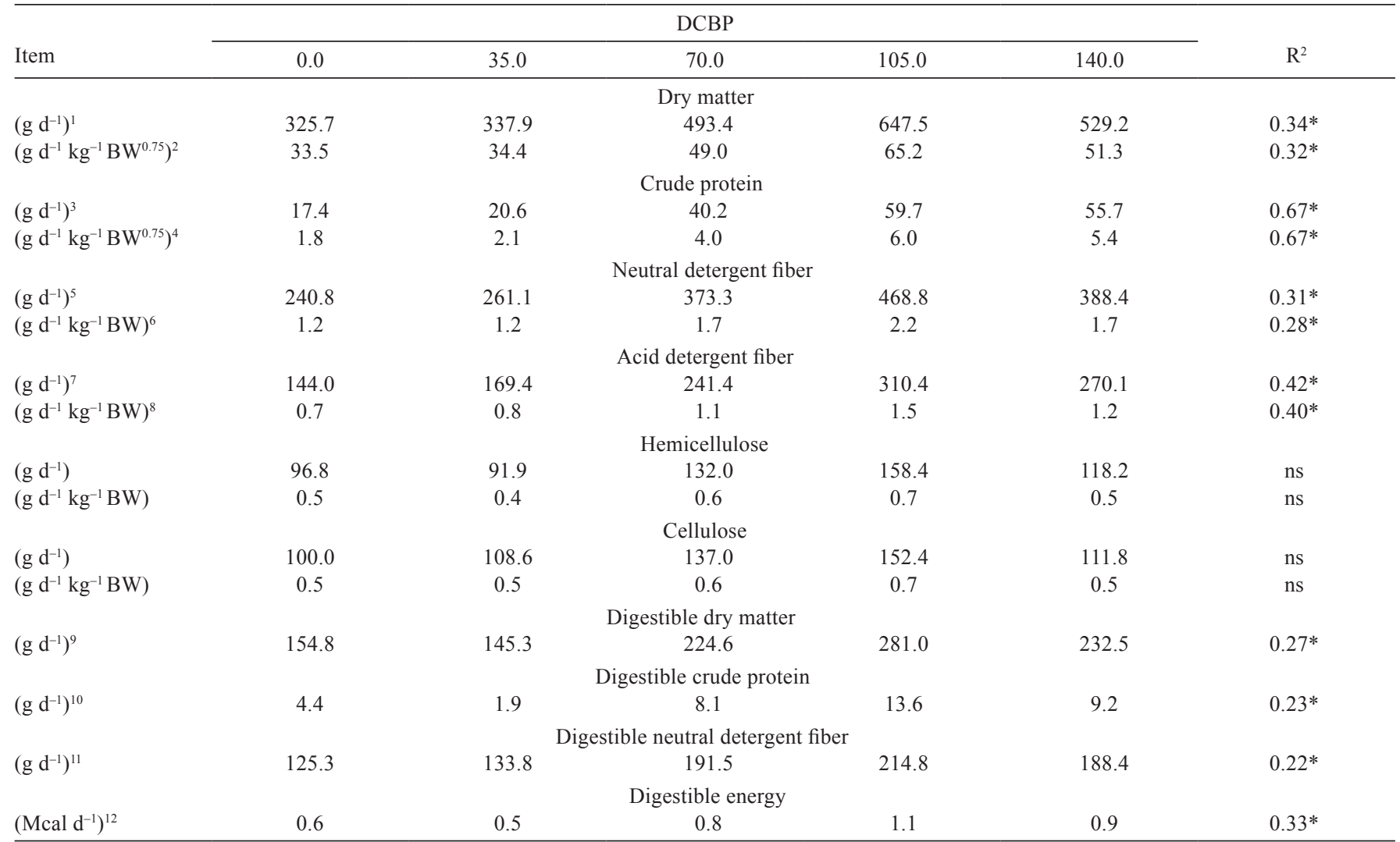

DCBP - by-product from dried cashew apple.

$*(\mathrm{P}<0.01)$ by the $\mathrm{t}$ test $($ student $) ; \mathrm{ns}-$ not significant.

${ }^{1} \mathrm{Y}=323.44+20.47 \mathrm{X}$.

${ }^{2} \mathrm{Y}=33.43+1.89 \mathrm{X}$.

${ }^{3} \mathrm{Y}=1.22+0.04 \mathrm{X}$

${ }^{4} \mathrm{Y}=0.23+0.04 \mathrm{X}$.

${ }^{5} \mathrm{Y}=246.09+14.36 \mathrm{X}$.

${ }^{6} \mathrm{Y}=1.19+0.06 \mathrm{X}$.

${ }^{7} \mathrm{Y}=148.47+11.23 \mathrm{X}$

${ }^{8} \mathrm{Y}=0.72+0.05 \mathrm{X}$

${ }^{9} \mathrm{Y}=151.55+8.25 \mathrm{X}$

${ }^{10} \mathrm{Y}=0.40+0.04 \mathrm{X}$.

${ }^{11} \mathrm{Y}=130.78+5.88 \mathrm{X}$

${ }^{12} \mathrm{Y}=0.55+0.03 \mathrm{X}$ 
respectively, with every $10.0 \mathrm{~g} \mathrm{~kg}^{-1}$ of inclusion of DCBP (Table 3 ). These data suggest that addition of DCBP improved the nutritional value of elephant-grass silage in this work.

The levels of addition of DCBP to the ensilage of elephant grass did not affect $(\mathrm{P}>0.05)$ the coefficients of $\mathrm{DA}$ of the nutrients or the $\mathrm{DE}$ and $\mathrm{NB}$ values of the diets (Table 4). The levels of DCBP had no effect $(\mathrm{P}>0.05)$ on NB. Only the silages with $105.0 \mathrm{~g} \mathrm{~kg}^{-1}$ of DCBP showed positive values.

The incubation period and the levels of addition of DCBP $(\mathrm{P}<0.05)$ in the ensilage of elephant grass interfered with the disappearance of DM (Table 5). For soluble fractions at time zero (0), the values varied from 189.4 to $221.6 \mathrm{~g} \mathrm{~kg}^{-1} \mathrm{DM}$. Throughout the incubation time, the silages showed increasing rates of disappearance of DM until $96 \mathrm{~h}(\mathrm{P}<0.05)$.
In the determination of the disappearance of $\mathrm{CP}$, both the incubation time and the levels of addition of DCBP in the ensilage of the elephant grass interfered with the disappearance of CP (Table 5). For NDF, an effect of incubation period and levels of addition of DCBP $(\mathrm{P}<0.05)$ was observed in the ensilage of elephant grass (Table 5). Regarding the soluble fractions at time zero (0), values varied from 72.1 to $115.7 \mathrm{~g} \mathrm{~kg}^{-1} \mathrm{NDF}$.

At the incubation time of $96 \mathrm{~h}$, the exclusive silages of elephant grass and the silages with 35.0, 70.0, 105.0, and $140.0 \mathrm{~g} \mathrm{~kg}^{-1}$ (as fed basis) of the DCBP showed the highest $(\mathrm{P}<0.05)$ NDF disappearance values, compared with the other incubation times. In this period, the silages with addition of DCBP showed similar mean NDF disappearance values $(\mathrm{P}>0.05)$ to that observed in the exclusive elephantgrass silage (Table 5).

Table 4 - Apparent digestibility of nutrients, digestible energy values, nitrogen balance, and coefficients of determination $\left(\mathrm{R}^{2}\right)$ of the silages

\begin{tabular}{|c|c|c|c|c|c|c|}
\hline \multirow[b]{2}{*}{ Nutrient } & \multicolumn{5}{|c|}{ DCBP } & \multirow[b]{2}{*}{$\mathrm{R}^{2}$} \\
\hline & 0.0 & 35.0 & 70.0 & 105.0 & 140.0 & \\
\hline Dry matter $^{1}$ & 475.0 & 417.6 & 452.4 & 437.7 & 437.5 & ns \\
\hline Crude protein ${ }^{1}$ & 244.1 & 50.6 & 190.8 & 234.7 & 162.2 & ns \\
\hline Neutral detergent fiber ${ }^{1}$ & 518.4 & 502.6 & 511.4 & 461.5 & 483.0 & $\mathrm{~ns}$ \\
\hline Acid detergent fiber ${ }^{1}$ & 483.4 & 442.7 & 476.5 & 418.1 & 459.0 & ns \\
\hline Hemicellulose $^{1}$ & 569.2 & 613.5 & 574.4 & 546.8 & 540.5 & ns \\
\hline Cellulose $^{1}$ & 619.5 & 660.6 & 797.0 & 833.1 & 891.6 & $\mathrm{~ns}$ \\
\hline Digestible energy $^{2}$ & 456.8 & 391.1 & 421.2 & 413.1 & 418.8 & ns \\
\hline Nitrogen balance ${ }^{3}$ & -2.27 & -2.46 & -1.34 & 0.26 & -1.32 & ns \\
\hline
\end{tabular}

DCBP - by-product from dried cashew apple.

ns - not significant.

${ }^{1} \mathrm{~g} \mathrm{~kg}^{-1}$.

2 Mcal kg-1 DM.

${ }^{3} \mathrm{~g} \mathrm{~d}^{-1}$.

Table 5 - Average disappearance $\left(\mathrm{g} \mathrm{kg}^{-1}\right)$ of the nutrients from silages at time zero and at different rumen-incubation times

\begin{tabular}{|c|c|c|c|c|c|}
\hline \multirow[b]{2}{*}{ Time (h) } & \multicolumn{5}{|c|}{$\mathrm{DCBD}$} \\
\hline & 0.0 & 35.0 & 70.0 & 105.0 & 140.0 \\
\hline \multicolumn{6}{|c|}{ Dry matter } \\
\hline 0 & $194.3 \mathrm{cdE}$ & $221.6 \mathrm{aE}$ & 212.9abE & $202.7 \mathrm{bcE}$ & $189.4 \mathrm{dE}$ \\
\hline 6 & $225.9 \mathrm{dD}$ & $261.6 \mathrm{aD}$ & $239.8 \mathrm{bcD}$ & $244.8 \mathrm{bD}$ & $228.2 \mathrm{cdD}$ \\
\hline 24 & $341.8 \mathrm{aC}$ & $323.9 \mathrm{bcC}$ & $317.7 \mathrm{cC}$ & $335.2 \mathrm{abC}$ & $323.7 \mathrm{bcC}$ \\
\hline 48 & $454.5 \mathrm{bB}$ & $493.4 \mathrm{aB}$ & $472.9 \mathrm{bB}$ & $468.2 \mathrm{bB}$ & $469.8 \mathrm{bB}$ \\
\hline 96 & $610.4 \mathrm{aA}$ & $607.9 \mathrm{aA}$ & $597.8 \mathrm{abA}$ & $613.5 \mathrm{aA}$ & $581.1 \mathrm{bA}$ \\
\hline \multicolumn{6}{|c|}{ Crude protein } \\
\hline 0 & $165.4 \mathrm{aE}$ & $122.0 \mathrm{bE}$ & $113.7 \mathrm{bE}$ & $92.3 \mathrm{cE}$ & $82.9 \mathrm{cE}$ \\
\hline 6 & $250.6 \mathrm{bD}$ & $280.3 \mathrm{aD}$ & $249.1 \mathrm{bD}$ & $282.6 \mathrm{cD}$ & $228.2 \mathrm{cD}$ \\
\hline 24 & $368.7 \mathrm{aC}$ & $344.5 b C$ & $328.4 \mathrm{cdC}$ & $337.8 \mathrm{bcC}$ & $314.7 \mathrm{dC}$ \\
\hline 48 & $471.7 \mathrm{bB}$ & $490.9 \mathrm{aB}$ & $475.2 \mathrm{bB}$ & $441.1 \mathrm{cB}$ & $421.7 \mathrm{~dB}$ \\
\hline 96 & $648.2 \mathrm{aA}$ & $589.0 \mathrm{bA}$ & $574.1 \mathrm{cA}$ & $550.2 \mathrm{cA}$ & $521.8 \mathrm{eA}$ \\
\hline \multicolumn{6}{|c|}{ Neutral detergent fiber } \\
\hline 0 & $72.1 \mathrm{bE}$ & $104.2 \mathrm{aE}$ & $115.5 \mathrm{aD}$ & $112.7 \mathrm{aD}$ & $115.7 \mathrm{aE}$ \\
\hline 6 & $130.8 \mathrm{abD}$ & 130.6abD & $137.1 \mathrm{aD}$ & $107.9 b D$ & $142.4 \mathrm{aD}$ \\
\hline 24 & $184.8 \mathrm{cC}$ & $199.1 \mathrm{bcC}$ & $195.2 \mathrm{cC}$ & $221.2 \mathrm{abC}$ & $212.9 \mathrm{aC}$ \\
\hline 48 & $332.1 \mathrm{cB}$ & $406.7 \mathrm{aB}$ & $386.9 \mathrm{aB}$ & $357.4 \mathrm{bB}$ & $384.3 \mathrm{aB}$ \\
\hline 96 & 533.7abA & $544.5 \mathrm{abA}$ & $542.4 \mathrm{abA}$ & $548.1 \mathrm{aA}$ & $521.2 \mathrm{bA}$ \\
\hline
\end{tabular}

DCBP - by-product from dried cashew apple.

$\mathrm{a}, \mathrm{b}, \mathrm{c}, \mathrm{d}, \mathrm{e}-\mathrm{means}$ followed by different letters in the row are different by the $\mathrm{t}$ test.

$\mathrm{A}, \mathrm{B}, \mathrm{C}, \mathrm{D}, \mathrm{E}-$ means followed by different letters in the column are different by the t test. 
Concerning the parameters of ruminal degradation of $\mathrm{DM}$, it was observed that in the soluble fraction, the silage with $35.0 \mathrm{~g} \mathrm{~kg}^{-1}$ DCBP showed the highest numerical value, when then a decrease was seen in the values of fraction a with the levels of addition of DCBP (Table 6). All degradation rates of fraction $b$ (c) remained with values below $0.02 \mathrm{~h}^{-1}$. The digestible-energy values remained practically constant with the levels of addition of DCBP; the same response was observed for the AD of these silages $(\mathrm{P}>0.05)$ (Table 4). The presence of tannin in the DCBP may also be a factor of reduction in disappearance of DM, since the main impact of tannins in animal nutrition is the ability of these compounds to form complexes with various types of molecules.

\section{Discussion}

The increase in DM intake $\left(\mathrm{g} \mathrm{d}^{-1}\right.$ and $\mathrm{g} \mathrm{kg}^{-1} \mathrm{~d}^{-1} \mathrm{LW}^{0.75}$ ) with addition of DCBP (Table 3 ) may stem from the greater DM content, as observed by Muck (1988), who stressed that this increase may be more closely related to the improvement in the silages' fermentation process, provided by the increased DM content, than to the moisture content in the silage. It is also evidenced that the intake of feeds has a close relationship with the amount of DM present in the diet, since the proportion of roughage, associated with the higher levels of water, determines the space occupied in the rumen, which may limit intake due to the rumen distension effect. Therefore, addition of DCBP to the ensilage of elephant grass may increase intake by improving the fermentation process and reducing the moisture content of the silages, as both occurrences were observed in the present experiment.
In this regard, the low voluntary intake of the silages was likely a combined effect of the nutritional value of the elephant grass and the concentrations of NDF and ADIN in DCBP.

Teles et al. (2010) did not observe an effect of the level of addition of DCBP in the ensilage of elephant grass on DM intake, possibly due to the effect of the ADIN content, which was greater than that observed in this study. This high ADIN content may be related to the Maillard reaction (Van Soest and Manson, 1991), because of possible heating during the ensiling process.

The linear effect of DCBP on CP intake (Table 3 ) may be a consequence of both the elevation in the $\mathrm{CP}$ contents and the DM intake from silages containing DCBP. According to the NRC (2007), the necessary CP intake for sheep weighing $25 \mathrm{~kg}$ is $32 \mathrm{~g} \mathrm{~d}^{-1}$; this requirement was met after the level of $70.0 \mathrm{~g} \mathrm{~kg}^{-1}$ of inclusion of DCBP (as fed basis).

The greater intakes of NDF and ADF result from the increase in the DM intake from silages with DCBP (Table 3). It is possible that this result also contributed to the increase in DM intake from silages, since, according to Mertens (1992), the ideal NDF level in the diet is not fixed, and it varies according to the net energy requirements of the animal. Thus, when the roughage aspect of the diet is a limiting factor, i.e., when the diet has a high NDF content, the animal needs to consume more to meet its energy requirements.

Lousada Jr. (2003) evaluated the NDF intake from pineapple, acerola (Malpighia emarginata), guava, melon, and passion fruit by-products and emphasized that despite the similarities in origin (by-products from fruit processing), the by-products have a large variation in NDF intake because of the nature of the fiber, which demonstrates the

Table 6 - Parameters of degradability and effective degradability, and coefficients of determination $\left(\mathrm{R}^{2}\right)$ of the nutrients of silages for the passage rates of $0.02,0.05$, and $0.08 \mathrm{~h}^{-1}$

\begin{tabular}{|c|c|c|c|c|c|c|c|}
\hline \multirow[b]{2}{*}{ DCBD } & \multicolumn{3}{|c|}{ Parameters $^{1}$} & \multicolumn{3}{|c|}{ Effective degradability } & \multirow[b]{2}{*}{$\mathrm{R}^{2}$} \\
\hline & $\mathrm{a}$ & $\mathrm{b}$ & $\mathrm{c}$ & $0.02 \mathrm{~h}^{-1}$ & $0.05 \mathrm{~h}^{-1}$ & $0.08 \mathrm{~h}^{-1}$ & \\
\hline \multicolumn{8}{|c|}{ Dry matter } \\
\hline 0.0 & 187.3 & 520.0 & 15.7 & 41.6 & 31.2 & 27.3 & 0.99 \\
\hline 35.0 & 213.9 & 520.0 & 1.43 & 43.0 & 32.9 & 29.3 & 0.97 \\
\hline 70.0 & 200.7 & 520.0 & 1.42 & 41.7 & 31.6 & 27.9 & 0.98 \\
\hline 105.0 & 198.4 & 520.0 & 1.52 & 42.3 & 32.0 & 28.1 & 0.99 \\
\hline 140.0 & 183.8 & 531.9 & 1.47 & 40.9 & 30.4 & 26.6 & 0.99 \\
\hline \multicolumn{8}{|c|}{ Crude protein } \\
\hline 0.0 & 186.6 & 626.1 & 1.36 & 44.0 & 32.0 & 27.8 & 0.98 \\
\hline 35.0 & 156.9 & 470.0 & 2.55 & 42.0 & 31.6 & 27.1 & 0.95 \\
\hline 70.0 & 140.3 & 479.4 & 2.42 & 40.3 & 29.7 & 25.2 & 0.97 \\
\hline 105.0 & 140.1 & 420.3 & 3.00 & 39.2 & 29.8 & 25.5 & 0.91 \\
\hline 140.0 & 114.0 & 427.0 & 2.80 & 36.3 & 26.7 & 22.5 & 0.97 \\
\hline
\end{tabular}

DCBP - by-product from dried cashew apple.

${ }^{1} \mathrm{a}$ - soluble fraction $\left(\mathrm{g} \mathrm{kg}^{-1}\right) ; \mathrm{b}$ - potentially soluble fraction $\left(\mathrm{g} \mathrm{kg}^{-1}\right) ; \mathrm{c}$ - degradation rate of $\mathrm{b}\left(\mathrm{g} \mathrm{kg}^{-1} \mathrm{~h}^{-1}\right)$. 
concept stated in NRC (2001), that the intake limit of $14.0 \mathrm{~g} \mathrm{~kg}^{-1} \mathrm{~d}^{-1} \mathrm{LW}$ of NDF in cattle should not be applied to diets containing by-products.

Pimentel et al. (2011) evaluated the intake of nutrients in sheep fed diets containing cashew nut meal (CNM) at the levels of $0,100.0,200.0$, and $300.0 \mathrm{~g} \mathrm{~kg}^{-1}$ of the concentrated diet. Neither dry matter nor crude protein intake was influenced by addition of CNM; however, the intakes of NDF and ADF showed a quadratic response to the increase in the dietary lipid level.

Although the addition of DCBP improved some chemical characteristics of the silages, e.g., the CP content (Table 2), this alteration was not sufficient to provide a better use of these feeds by the animals, based on coefficients of DA of the nutrients or the DE and NB values of the diets (Table 4). A possible explanation for this fact is the high percentage of NDIN and ADIN, which have their use limited by the rumen microorganisms (Van Soest and Manson, 1991; Van Soest, 1994). Thus, because a good portion of the nitrogen present in the feed formed complexes with fibrous components (NDIN and ADIN), this might have contributed to the low digestibility values of the silages' nutrients.

In diets with low availability of nitrogen compounds and rich in NDF, the supply of rumen-degradable protein is limiting to microbial growth; thus, the cell wall digestion is compromised and feed intake is reduced (Van Soest, 1994).

The lignin contents of the silages also increased as the inclusion of DCBP in the ensilage of elephant grass was increased (Table2). Diets rich in lignin may limit the potential of digestion of fibrous carbohydrates. Hence, even if the partially digestible components were increased by elevating the inclusion of DCBP, the indigestible components were also increased, which might have contributed to the lack of alterations in the $\mathrm{AD}$ of the nutrients from the silages when assessed in vivo.

Thus, the low AD contents of the nutrients obtained in this study may be a consequence of both the low availability of nitrogen in the silages, through the increased ADIN, and the increased amounts of lignin in the silages with addition of DCBP (Table 4). Evaluating levels of addition (0, 40.0, $80.0,120.0$, and $160.0 \mathrm{~g} \mathrm{~kg}^{-1}$; as fed) of dried cashew apple in the ensilage of elephant grass, Teles et al. (2010) also did not observe effects of the by-product on the AD of DM, CP, NDF, EE, or total carbohydrates, although they observed a linear decrease in the AD of the silages' ADF.

Working with pineapple, acerola, guava, passion fruit, and melon by-products, Lousada Jr. (2003) found $\mathrm{AD}$ values of $\mathrm{NDF}$ and $\mathrm{ADF}$ of 508.0 and $518.0 ; 168.0$ and $82.0 ; 177.0$ and $130.0 ; 562.0$ and 654.0 ; and 386.5 and $387.4 \mathrm{~g} \mathrm{~kg}^{-1} \mathrm{DM}$, respectively, stressing that the highest $\mathrm{AD}$ values of NDF were observed in the by-products with the lowest lignin content. Pimentel et al. (2011) found that the AD of DM, CP, NDF, and ADF were not influenced by addition of CNM to the diets. Teles et al. (2010) observed an increasing linear response of NB to inclusion of dried cashew apple in the ensilage of elephant grass.

The soluble fraction values can be considered high, since they refer to fragmented feeds (Table 5). Thus, the soluble fraction would be represented by the sugars, remaining nitrogen compounds from the fermentation in the silo and sample loss. Throughout the incubation time, the silages showed increasing rates of disappearance of DM until $96 \mathrm{~h}(\mathrm{P}<0.05)$. It is believed that at this time the silages had already reached the maximum disappearance of DM. According to Sampaio (1994), the incubation period of $96 \mathrm{~h}$ is sufficient for studies of ruminal evaluation in situ of roughages, because it is considered that until this time it is possible to detect changes in the degradability of the material. However, considering the levels of addition of DCBP in every period individually, no consistent variations were observed in the values of disappearance of DM.

The results of disappearance of CP (Table 5) confirm the low values found for $\mathrm{AD}\left(176.0 \mathrm{~g} \mathrm{~kg}^{-1} \mathrm{CP}\right.$ in $\left.\mathrm{DM}\right)$ of this parameter (Table 4), and also help to explain the low intakes detected. The initial loss of the fibrous fraction (NDF) (Table 5) was probably caused by the greater loss of material through the pores of the bags at the time of washing, since the fibrous fraction is predominantly soluble. Despite the increase in the concentrations of lignin and ADIN, it was demonstrated that the waste displayed good use of the fiber as compared with the silage with elephant grass only, which may be related to the particle size of the by-product, providing a larger contact area for the activity of rumen bacteria.

Degradation rates of fraction $b$ (c) with values below $0.02 \mathrm{~h}^{-1}$ (Table 6) may indicate longer residence of the feed in the rumen, which may lead to reduced intake through the distension of the gastrointestinal tract, before the energy requirements are met. Sampaio (1994) stated that a degradation rate lower than $0.02 \mathrm{~h}^{-1}$ is indicative of lowquality feeds, as it requires a long period in the rumen for proper digestion. Therefore, it is possible that addition of DCBP to the ensilage of elephant grass compromises the nutritional quality of the feed, due to its reduced rate of utilization by rumen microorganisms.

Regarding the $\mathrm{CP}$, despite the increase in the degradation rate (c) of the silages with inclusion of DCBP, a reduction was observed in the DE values (Table 6) with 
inclusion of the by-product, possibly due to the reduction of the soluble fraction.

Rêgo et al. (2010a) studied the degradation in situ of DM, CP, and NDF of elephant-grass silages containing five levels $\left(0,40.0,80.0,120.0\right.$, and $160.0 \mathrm{~g} \mathrm{~kg}^{-1}$; ensiled as fed basis) of inclusion of annatto seed by-product (ASB). The authors found an increase in disappearance of DM until the level of $133.7 \mathrm{~g} \mathrm{~kg}^{-1}$ of addition of ASB to the ensilage of elephant grass for $28 \mathrm{~h}$ of incubation. Similarly to the present study, the disappearance of NDF at $96 \mathrm{~h}$ of incubation increased up to $160.0 \mathrm{~g} \mathrm{~kg}^{-1}$ of addition. For the studied set of degradation parameters, it was observed that the inclusion level of $160.0 \mathrm{~g} \mathrm{~kg}^{-1}$ ASB displayed higher values for the potential and effective degradability of the studied variables. The authors concluded that inclusion of the annatto seed by-product in the ensilage of elephant grass resulted in silages with greater potential and effective degradability, which was not observed with DCBP.

The type of response found for silages with DCBP may be due to the greater difficulty that the microorganisms had to reach the protein matrix, which is protected by the fibrous fraction and by the interactions existing with lignin and/or tannins.

In this regard, the results obtained in this study indicate that there is a need for protein supplementation in diets that include DCBP. Based on the rumen-degradation characteristics, the supplements should present decreasing rates of ruminal degradation of $\mathrm{CP}$.

\section{Conclusions}

The addition of by-product from dried cashew apple improves the nutritional value of elephant-grass silage mainly by improving nutrient intake. Dried cashew apple can be included at up to $140 \mathrm{~g} \mathrm{~kg}^{-1}$ (as fed basis), in silages of elephant grass, but high levels of acid detergent insoluble nitrogen may compromise the use and availability of nitrogen to animals.

\section{References}

Akaike, H. 1974. A new look at the statistical model identification. IEEE Transactions on Automatic Control 19:716-723.

AOAC - Association of Official Analytical Chemists. 1990. Official methods of analysis. 15th ed. AOAC, Arlington, VA.

Agostini-Costa, T. S.; Lima, A. and Lima, M. V. 2003. Determinação de tanino em pedúnculo de caju: método da vanilina versus método do butanol ácido. Química Nova 26:763-765.

Borges, P. H. R.; Azevedo, A. R.; Sales, R. O.; Arruda, F. A. V. and Alves, A. A. 2001. Desempenho de ovinos alimentados com diferentes níveis de pseudofruto seco do cajueiro. Revista Científica de Produção Animal 3:24-34.
Dantas Filho, L. A.; Lopes, J. B.; Vasconcelos, V. R.; Oliveira, M. E.; Alves, A. A.; Araújo, D. L. C. and Conceição, W. L. F. 2007. Inclusão de polpa de caju desidratada na alimentação de ovinos: desempenho, digestibilidade e balanço de nitrogênio. Revista Brasileira de Zootecnia 36:147-154.

Ferreira, A. C. H.; Neiva, J. N. M.; Rodriguez, N. M.; Lôbo, R. N. B. and Vasconcelos, V. R. 2004. Valor nutritivo das silagens de capimelefante com diferentes níveis de subprodutos da indústria do suco de caju. Revista Brasileira Zootecnia 33:1380-1385.

Ferreira, A. C. H.; Neiva, J. N. M.; Rodriguez, N. M.; Campos, W. E. and Borges, I. 2007. Características químicas e fermentativas do capim-elefante ensilado com níveis crescentes de subproduto da agroindústria do caju. Ciência Animal Brasileira 8:723-731.

Licitra, G.; Hernandez, T. M. and Van Soest, P. J. 1996. Standardization of procedures for nitrogen fractionation of ruminant feeds. Animal Feed Science and Technology 57:347-358.

Lousada Jr., J. E. 2003. Digestibilidade aparente de subprodutos do processamento de frutas em ovinos. Dissertação (M.Sc.). Universidade Federal do Ceará, Fortaleza.

Luciano, R. C.; Araújo, L. F.; Aguiar, E. M.; Pinheiro, L. E. and Nascimento, D. S. 2011. Revisão sobre a potencialidade do pedúnculo do caju na alimentação animal. Tecnologia \& Ciência Agropecuária 5:53-59.

McDonald, I. 1981. A revised model for the estimation of protein degradability in the rumen. The Journal of Agricultural Science 96:251-252

Mertens, D. R. 1992. Análise da fibra e sua utilização na avaliação de alimentos e formulação de rações. p.188. In: Simpósio International de Ruminantes, Lavras.

Muck, R. E. 1988. Factors influencing silage quality and their implications for management. Journal of Dairy Science 71:2992-3002.

NRC - National Research Council. 2001. Nutrient requirements of dairy cattle. 7th ed. NRC, Washington, DC.

NRC - National Research Council. 2007. Nutrient requirement of small ruminants. 1st ed. NRC, Washington, DC.

Ørskov, E. R. and McDonald, P. 1979. The estimation of protein degradability in the rumen from incubation measurements weighed according to rate of passage. Journal Agricultural Science 92:499-503.

Pimentel, P. G.; Pereira, E. S.; Queiroz, A. C. D.; Mizubuti, I. Y.; Regadas Filho, J. G. L. and Maia, I. S. G. 2011. Intake, apparent nutrient digestibility and ingestive behavior of sheep fed cashew nut meal. Revista Brasileira de Zootecnia 40:1128-1133.

Rêgo, A. C.; Cândido, M. J. D.; Pereira, E. S.; Feitosa, J. V. and Rêgo, M. M. T. 2010a. Degradação de silagens de capim-elefante contendo subproduto do urucum. Revista Ciência Agronômica 41:482-489.

Rêgo, M. M. T.; Neiva, J. N. M.; Rêgo, A. C. D.; Cândido, M. J. D.; Carneiro, M. S. D. S. and Lôbo, R. N. B. 2010b. Chemical and bromatological characteristics of elephant grass silages with the addition of dried cashew stalk. Revista Brasileira de Zootecnia 39:255-261

Sampaio, I. B. M. 1994. Contribuições estatísticas e de técnica experimental para ensaios de degradabilidade de forragens quando avaliada in situ. p.81. In: Anais da 31 $\stackrel{\text { a }}{ }$ eunião Anual da Sociedade Brasileira de Zootecnia. Sociedade Brasileira de Zootecnia, Maringá.

Silva, J. F. C. and Leão, M. I. 1979. Fundamentos de nutrição dos ruminantes. Livroceres, Piracicaba.

Silva, L. M.; Oliveira, C. H. A.; Rodrigues, F. V.; Rodrigues, M. R. C.; Bezerra, F. J.; Silva, A. M.; Lemos, J. C.; Fernandes, A. A. O. and Rondina, D. 2011. Desempenho e características da carcaça de cordeiros alimentados com bagaço de caju. Archivos de Zootecnia 60:777-786. 
Teles, M. M.; Neiva, J. N. M.; Clementino, R. H.; Rêgo, A. C. D.; Cândido, M. J. D. and Restle, J. 2010. Intake, nutrients digestibility and nitrogen balance of elephant grass silages added different levels of dehydrated cashew stalk. Ciência Rural 40:397-403.

Tomich, T. R. and Sampaio, I. B. M. 2004. A new strategy for the determination of forage degradability with an in situ technique through the use of one fistulated ruminant. The Journal of Agricultural Science 142:589-593.
Van Soest, P. J. 1994. Nutritional ecology of the ruminant. 2th ed. Cornell University Press, Ithaca, NY.

Van Soest, P. J. and Manson, V. C. 1991. The influence of the Maillard reaction upon the nutritive value of fibrous feed. Animal Feed Science and Technology 32:45-53.

Van Soest, P. J.; Robertson, J. B. and Lewis, B. A. 1991. Methods for dietary fiber, neutral detergent fiber, and nonstarch polysaccharides in relation to animal nutrition. Journal of Dairy Science 74:3583-3597. 